\title{
ANALYSIS OF CLINICAL EFFICACY AND SAFETY OF INTRAVENOUS USE OF DICLO- FENAC FOR THE PREVENTION OF POSTOPERATIVE PAIN: CURRENT STATUS AND STRATEGIC ASPECT
}

\author{
E. Litvinova
}

\begin{abstract}
Метою роботи є аналіз та систематизація даних літератури щеоо сучасного стану $і$ стратегічного аспекту внутрішньовенного використання диклофенака для попередження післяопераційного болю, а саме клінічної ефективності та безпеки.

Матеріали та методи. Дослідження проводилися з використанням баз даних в мережі Інтернет: PubMed; Адміністрації з контролю за ліками та харчовими продуктами (Food and Drug Administration), Європейського агентства лікарських засобів (European Medicines Agency). Використано ретроспективний, логічний методи дослідження, контент-аналіз.
\end{abstract}

Результати. Проведений аналіз клінічних даних свідчить, щуо диклофенак натрію при внутрішньовенному введенні виявляє опіоїдзберегаючий ефект, є ефективним у паиієнтів, які відчувають гострий післяопераційний біль, або як частина мультимодальної анальгетичної стратегї для досягнення періопераційоного контролю болю. Зазначене розширює можливості купірування больового синдрому $і$ сприяє прискоренню реабілітації після хірургічних втручань, зменшує потребу в наркотиках. Частота побічних ефектів при внутрішньовенному введенні диклофенаку була схожою з такою при інших видах лікування. Нові можливості стратегічного аспекту внутрішньовенного використання диклофенаку пов'язані із застосуванням препарату Dyloject, Hospira Inc., США, щуо має поліпшену розчинність, менший час введення, ніж проведення інфузії. Частота виникнення тромбофлебіту на тлі Dyloject була виражена в меншій мірі порівняно з препаратом Voltarol.

Висновки. Таким чином, досвід клінічного внутрішньовенного використання диклофенака натрію для попередження післяопераційного болю підтвердив його ефективність, сприятливий профіль безпеки $i$ можливість зменшувати потребу в наркотиках. Перспективним стратегічним аспектом є створення вітчизняних препаратів диклофенаку натрію для внутрішньовенного введення, які мають поліпшену розчинність, менший час введення, ніж інфузії $і$ не мають додаткового ризику щзодо безпеки.

Ключові слова: диклофенак, післяопераційний біль, опіоїдзберегаючий ефект, внутрішньовенне введення.

\section{Introduction}

Nonsteroidal anti-inflammatory drugs (NSAIDs) are a group of drugs that are widely used in clinical practice. More than thirty million people worldwide receive NSAIDs daily, with $40 \%$ of those patients over 60 years of age. About $20 \%$ of inpatients receive NSAIDs. Their popularity is explained by the fact that they have antiinflammatory, analgesic and antipyretic effects and provide relief to patients with relevant symptoms (inflammation, pain, fever), which are noted in many diseases [1].

The favorable efficacy / safety ratio, as evidenced in numerous adequate clinical studies, makes it possible to consider NSAIDs - diclofenac as the drug of choice for the treatment of degenerative-dystrophic diseases of the musculoskeletal system and other conditions accompanied by pain of different localization and intensity. Diclofenac sodium was first synthesized in 1964 and since 1974 has been widely used by doctors around the world. Using a production diversification strategy, diclofenac dosage forms for topical application, tablet formulations, injection forms were developed to improve the efficacy, tolerability and convenience of the patient [2].
In the general structure of drug therapy, postoperative pain, NSAIDs are analgesics, which are the most commonly prescribed worldwide. WHO recommends the designation of NSAIDs as the first step in postoperative analgesia. According to the Practical Guide to the Treatment of Postoperative Pain (American Society for Pain Management, 2016), NSAIDs are the most important components in a system of multimodal analgesia. Their use, as a component of multimodal anesthesia, reduces the need for opioids and, accordingly, the frequency of postoperative nausea and vomiting, reduce the degree of sedation, provide early mobilization [3].

In intense acute pain (surgery), the speed of pain relief can be of fundamental importance. In this case, intravenous use of NSAIDs is justified [4, 5]. However, the benefit of such administration is maintained only during the first day of treatment.

In the short term after surgery, for the pain relief purpose NSAIDs are often prescribed, along with opioids (such as morphine). However, NSAIDs can cause bleeding (such as in the incision or wound) and lead to damage to the kidneys and intestines $[6,7]$. Evidence is available 
that intravenous diclofenac is effective in reducing pain after surgery in adults, but it is not fully known how safe it is to use in these conditions.

The aim of the work is the analysis and systematization of literature data on the current state and strategic aspect of intravenous use of diclofenac for the prevention of postoperative pain, namely clinical efficacy and safety.

\section{Planning (methodology) of research}

The following research plan has been developed:

- comparative analysis of diclofenac sodium dosage forms for injections which were registered at the Food and Drug Administration, European Medicines Agency, as well as are presented in the British National Formulary;

- comparative analysis of controlled clinical studies of the efficacy and safety of various injectable forms of diclofenac sodium;

- analysis of data from more than one study, including any integrated analyzes, meta-analyzes, comparative analyzes of studies;

- determination of perspectives of practical medical application of systematic results and directions of further research on the topic.

\section{Materials and methods}

Studies were conducted using databases on the Internet: PubMed; Food and Drug Administration, European Medicines Agency. It has used retrospective, logical, research methods, content analysis.

Injectable preparations containing diclofenac sodium $75 \mathrm{mg}$, propylene glycol and benzyl alcohol, have been available in the UK since 1997 and are widely used in many countries [2]. The intravenous administration of this injectable form of diclofenac sodium is not indicated in the instructions for use in all European countries, according to the European Medicines Agency. But, diclofenac, solution for injection, $75 \mathrm{mg} / 3 \mathrm{ml}$ (for intravenous infusion), registered in countries (Austria, Belgium, Bulgaria, Czech Republic, Greece, Hungary, Ireland, Latvia, Lithuania, Luxembourg, Malta, Portugal, Romania, Slovakia, Sweden, the Netherlands, and the United Kingdom) with strict regulatory authorities. It should be noted that the drug Voltarol, solution for injection (Novartis Pharmaceuticals UK Ltd) for the prevention of postoperative pain in the form of intravenous infusions is presented in the British National Formulary (2018-2019), containing the main provisions of the system to ensure effective and safe pharmacotherapy [8]. However, these drugs require a long infusion time when administered intravenously. A new Dyloject injectable drug, Hospira Inc., USA, has been approved in the United States for $37.5 \mathrm{mg}$ sodium diclofenac and includes hydroxypropyl- $\beta$-cyclodextrin for increased solubility with $\mathrm{pH}$ modifiers and monothioglycerin [9]. Unlike the known diclofenac sodium injectables, Dyloject does not produce propylene glycol, and improved solubility is achieved by the hydroxypropyl- $\beta$ cyclodextrin excipient, which also shortens the time of intravenous administration.

\section{Results of the research}

Table 1 presents the results of the analysis and systematization of the clinical efficacy and tolerability of the use of diclofenac to prevent postoperative pain with intravenous administration.

Table 1

Efficacy and tolerability of diclofenac for the prevention of postoperative pain during intravenous administration

\begin{tabular}{|c|c|c|}
\hline No. & Research & Efficacy and tolerability of diclofenac \\
\hline 1 & 2 & 3 \\
\hline 1 & $\begin{array}{l}\text { Retrospective, total hip arthroplasty } \\
{[10]}\end{array}$ & $\begin{array}{l}\text { Adjunctive intravenous administration of diclofenac reduces opioid } \\
\text { consumption and increases satisfaction in primary total hip arthroplas- } \\
\text { ty }\end{array}$ \\
\hline 2 & $\begin{array}{l}2 \text { double-blind, randomized, placebo- } \\
\text { controlled, surgical orthopedics }(n=608) \\
{[11]}\end{array}$ & $\begin{array}{l}\text { Injectable hydroxypropyl- } \beta \text {-cyclodextrin-diclofenac reduced the need } \\
\text { for postoperative opioids after abdominal / pelvic or orthopedic sur- } \\
\text { gery }\end{array}$ \\
\hline 3 & $\begin{array}{l}\text { Multicenter, randomized, double, blind, } \\
\text { surgical orthopedics }(n=277)[12]\end{array}$ & $\begin{array}{l}\text { Hydroxypropyl- } \beta \text {-cyclodextrin-diclofenac is safe and effective in } \\
\text { acute moderate and severe pain after orthopedic surgery, significantly } \\
\text { reducing the use of morphine }\end{array}$ \\
\hline 4 & Pilot, cholecystectomy $(n=50)[13]$ & $\begin{array}{l}\text { It has established effectiveness of intravenous diclofenac for laparo- } \\
\text { scopic pain after cholecystectomy }\end{array}$ \\
\hline 5 & $\begin{array}{l}\text { Randomized, surgical oncology proce- } \\
\text { dures }(n=70)[14]\end{array}$ & $\begin{array}{l}\text { Intravenous infusion of diclofenac is considered as a safe alternative } \\
\text { to infusion of tramadol for the treatment of pain after extensive surgi- } \\
\text { cal oncology procedures }\end{array}$ \\
\hline 6 & $\begin{array}{l}\text { Pilot, obstetrics and gynecology } \\
(n=100)[15]\end{array}$ & $\begin{array}{l}\text { It has established efficacy in reducing pain by intravenous paraceta- } \\
\text { mol and intravenous diclofenac administration, relative safety }\end{array}$ \\
\hline 7 & $\begin{array}{l}\text { Prospective, double-blind, randomized, } \\
\text { surgical procedure }(n=120)[16]\end{array}$ & $\begin{array}{l}\text { Both paracetamol and diclofenac preparations provided analgesia for } \\
\text { intravenous postoperative administration without any significant side } \\
\text { effects }\end{array}$ \\
\hline 8 & $\begin{array}{l}\text { Double-blind, randomized, placebo- } \\
\text { controlled, } \\
\text { hip and knee replacement }(\mathrm{n}=102)[17]\end{array}$ & $\begin{array}{l}\text { Preoperative intravenous administration of diclofenac } 75 \mathrm{mg} \text { or ke- } \\
\text { torolac } 60 \mathrm{mg} \text { significantly reduces the need for morphine and associ- } \\
\text { ated side effects after major orthopedic surgery }\end{array}$ \\
\hline 9 & $\begin{array}{l}\text { Randomized, double-blind, placebo- } \\
\text { controlled, knee arthroplasty }(\mathrm{n}=64)[18]\end{array}$ & $\begin{array}{l}\text { In the first day after arthroplasty of the knee joint diclofenac and } \\
\text { ketoprofen had an opioid-saving effect }\end{array}$ \\
\hline
\end{tabular}


continuation of the Table 1

\begin{tabular}{|c|l|l|}
\hline 1 & \multicolumn{1}{|c|}{2} & \multicolumn{1}{|c|}{3} \\
\hline 10 & $\begin{array}{l}\text { 24 prospective and retrospective: 12 in } \\
\text { abdominal surgery, 7 in orthopedic } \\
\text { surgery and 5 in pediatric surgery [19] }\end{array}$ & $\begin{array}{l}\text { NSAIDs reduced opioid consumption while providing adequate pain } \\
\text { control }\end{array}$ \\
\hline 11 & $\begin{array}{l}\text { A randomized, double-blind, placebo- } \\
\text { controlled, adenoidectomy (n=150) [20] }\end{array}$ & $\begin{array}{l}\text { Diclofenac, intravenously during surgery has an analgesic effect in } \\
\text { the immediate postoperative period }\end{array}$ \\
\hline 12 & $\begin{array}{l}\text { A randomized, double-ended study, } \\
\text { dentistry (n=50) [21] }\end{array}$ & $\begin{array}{l}\text { Preoperative intravenous diclofenac 75 mg is more effective than } \\
\text { tramadol 50 mg in the prevention of postoperative dental pain }\end{array}$ \\
\hline 13 & Randomized, surgery (n=82) [22] & $\begin{array}{l}\text { It has established decreased postoperative pain and need for drugs } \\
\text { with intravenous diclofenac }\end{array}$ \\
\hline 14 & $\begin{array}{l}\text { Randomized, placebo-controlled, den- } \\
\text { tistry (n=169) [23] }\end{array}$ & $\begin{array}{l}\text { Single doses of intravenous diclofenac provide significant pain relief } \\
\text { after surgery on the third molar }\end{array}$ \\
\hline 15 & $\begin{array}{l}\text { A prospective, randomized, double- } \\
\text { blind, placebo-controlled trial } \\
\text { caesarean section (n=90) [24] }\end{array}$ & $\begin{array}{l}\text { Intravenous administration of diclofenac reduced the need for mor- } \\
\text { phine }\end{array}$ \\
\hline
\end{tabular}

\section{Discussion of the results}

The supplied results indicate that diclofenac sodium when administered intravenously is effective and safe in patients experiencing acute postoperative pain, or as part of a multimodal analgesic strategy to achieve perioperative pain control.

Along with a wide range of pharmacological action, high therapeutic efficacy, a number of side effects of diclofenac with intravenous administration should be noted.

The results of the Cochrane review (2018) of 8 studies involving 1756 people in whom diclofenac was administered intravenously to relieve pain after surgery in adults indicate that diclofenac is more effective than placebo and similar to other NSAIDs. Studies did not provide sufficient information on adequate assessment of side effects, but their incidence was similar to that seen with other treatments [25].

A safety analysis of 7 single-dose clinical trials was performed involving 531 patients who received either a rapid intravenous Dyloject bolus or a 30-minute intravenous infusion of Voltarol containing diclofenac sodium, propylene glycol and benzyl alcohol. The incidence of thrombophlebitis, observed, as an undesirable phenomenon after Dyloject treatment, was $1.2 \%$ (5 of 423) compared to $6.5 \%$ (7 of 108) after Voltarol [26].

In the study of the pharmacokinetics of intravenous Dyloject compared with Voltarol, no serious side effects were observed [27]. No clinically relevant changes in clinical laboratory tests, ECGs or indicators of vital function were found.

Dyloject has been investigated for the treatment of moderate-to-severe postoperative pain in 1289 patients $\geq$ $\geq 65$ years of age. The overall incidence of adverse events in patients aged $65-74$ or $\geq 75$ years was similar to patients aged $<65$ years [28].

Studies by other authors also confirm the good tolerability of the $75 \mathrm{mg} / 1 \mathrm{ml}$ diclofenac sodium solution, which was administered intravenously [29].

Post-operative use of Dyloject has been reported to pose no additional risk for cardiovascular safety compared to placebo [30].
Although numerous placebo-controlled studies of diclofenac, a solution for injection, are important evidence of its efficacy and tolerability, there is a higher degree of evidence of its clinical benefits. A widely recognized standard for evidence-based medicine is multicenter research data.

In a prospective, randomized multicenter trial, the risk of death, increased bleeding at the site of surgery, gastrointestinal bleeding, acute renal failure, and allergic reactions, with parenteral and oral administration of ketorolacene or diclofenac compared to dicloprolac was evaluated. Patients were observed within 30 days after surgery. A total of 11,245 patients were screened in 49 European hospitals. The overall risk of serious side effects with the use of diclofenac and NSAIDs in the study was very low.

Conducted clinical data analysis indicates that diclofenac sodium, when administered intravenously, has an opioid-saving effect, is effective in patients experiencing acute postoperative pain, or as part of a multimodal analgesic strategy to achieve perioperative pain control.

Limitations of research. A limitation of the study is the small sample size $(<100$ patients) of some previously conducted clinical studies of the efficacy and safety of injectable forms of diclofenac sodium.

Prospects for further development of this field. It is promising to create domestic diclofenac sodium preparations for intravenous administration, which have improved solubility, and to conduct large-scale population studies to determine the risks of serious side effects associated with intravenous diclofenac compared with other injections.

\section{Conclusions}

Thus, the experience of clinical intravenous use of diclofenac sodium for the prevention of postoperative pain has confirmed its efficacy, favorable safety profile and the ability to reduce the need for opiates. The promising strategic aspect is the creation of domestic diclofenac sodium preparations for intravenous administration, which have improved solubility, shorter administration time than infusions and have no additional safety risk. 


\section{References}

1. Walker, C., Biasucci, L. M. (2017). Cardiovascular safety of non-steroidal anti-inflammatory drugs revisited. Postgraduate Medicine, 130 (1), 55-71. doi: http://doi.org/10.1080/00325481.2018.1412799

2. Altman, R., Bosch, B., Brune, K., Patrignani, P., Young, C. (2015). Advances in NSAID Development: Evolution of Diclofenac Products Using Pharmaceutical Technology. Drugs, 75 (8), 859-877. doi: http://doi.org/10.1007/s40265-015-0392-z

3. Chou, R., Gordon, D. B., de Leon-Casasola, O. A., Rosenberg, J. M., Bickler, S. et al. (2016). Management of Postoperative Pain: A Clinical Practice Guideline From the American Pain Society, the American Society of Regional Anesthesia and Pain Medicine, and the American Society of Anesthesiologists' Committee on Regional Anesthesia, Executive Committee, and Administrative Council. The Journal of Pain, 17 (2), 131-157. doi: http://doi.org/10.1016/j.jpain.2015.12.008

4. Pitchon, D. N., Dayan, A. C., Schwenk, E. S., Baratta, J. L., Viscusi, E. R. (2018). Updates on Multimodal Analgesia for Orthopedic Surgery. Anesthesiology Clinics, 36 (3), 361-373. doi: http://doi.org/10.1016/j.anclin.2018.05.001

5. Yoshida, M., Shimizu, Y., Yoshida, K., Mukai, A., Doi, M., Irifune, M. (2018). Effective Postoperative Analgesia Using Intravenous Flurbiprofen and Acetaminophen. Journal of Oral and Maxillofacial Surgery, 76 (9), 1869-1872. doi: http://doi.org/10.1016/j.joms.2018.03.031

6. Elia, N., Lysakowski, C., Tramèr, M. R. (2005). Does Multimodal Analgesia with Acetaminophen, Nonsteroidal Antiinflammatory Drugs, or Selective Cyclooxygenase-2 Inhibitors and Patient-controlled Analgesia Morphine Offer Advantages over Morphine Alone? Anesthesiology, 103 (6), 1296-1304. doi: http://doi.org/10.1097/00000542-200512000-00025

7. Marret, E., Kurdi, O., Zufferey, P., Bonnet, F. (2005). Effects of Nonsteroidal Antiinflammatory Drugs on Patientcontrolled Analgesia Morphine Side Effects. Anesthesiology, 102 (6), 1249-1260. doi: http://doi.org/10.1097/00000542-20050600000027

8. British National Formulary 76 (2018). London: Pharmaceutical Press, 1640. doi: http://doi.org/10.18578/bnf.147942626

9. Hoy, S. M. (2016). Diclofenac Sodium Bolus Injection (DylojectTM): A Review in Acute Pain Management. Drugs, 76 (12), 1213-1220. doi: http://doi.org/10.1007/s40265-016-0619-7

10. George, N. E., Gurk-Turner, C., Castrodad, I. M. D., Etcheson, J. I., Mohamed, N. S., Gwam, C. U. et. al. (2019). Adjunctive Intravenous Diclofenac Decreases Opioid Consumption and Increases Satisfaction in the Primary Total Hip Arthroplasty Population. Surgical Technology International, 34, 456-461.

11. Gan, T., Singla, N., Daniels, S. E., Hamilton, D., Lacouture, P., Reyes, C., Carr, D. (2016). Postoperative opioid sparing with injectable hydroxypropyl-\&beta;-cyclodextrin-diclofenac: pooled analysis of data from two Phase III clinical trials. Journal of Pain Research, 10, 15-29. doi: http://doi.org/10.2147/jpr.s106578

12. Daniels, S., Melson, T., Hamilton, D. A., Lang, E., Carr, D. B. (2013). Analgesic Efficacy and Safety of a Novel Injectable Formulation of Diclofenac Compared With Intravenous Ketorolac and Placebo After Orthopedic Surgery. The Clinical Journal of Pain, 29 (8), 655-663. doi: http://doi.org/10.1097/ajp.0b013e318270f957

13. Jenifer, M., Radhesh, H. (2019). A study on efficacy of intravenous diclofenac and ketorolacon post laparoscopic cholecystectomy pains. International Journal of Science and Research, 8 (11), 217-221.

14. Binay, T., Mukti, D., Krishna, K., Bishal, S. (2018). Intravenous Diclofenac vs. Tramadol infusion for Post-operative Pain Management: A Randomized Trial. Nepalese Journal of Cancer, 2 (1), 38-42. doi: http://doi.org/10.3126/njc.v2i1.25649

15. Agrawal, S. A., Nikhate, S. D., Thakur, M. M., Bal, H. (2019). A study of comparison of efficacy and side effects of intravenous paracetamol and intravenous diclofenac as a postoperative analgesic. International Journal of Reproduction, Contraception, Obstetrics and Gynecology, 8 (9), 3684-3688. doi: http://doi.org/10.18203/2320-1770.ijrcog20193798

16. Shah, U., Dudhwala, K., Vakil, M. (2019). Prospective, double-blind randomized study of comparison of analgesic efficacy of parenteral paracetamol and diclofenac for postoperative pain relief. Journal of Anaesthesiology Clinical Pharmacology, 35 (2), 188-191. doi: http://doi.org/10.4103/joacp.joacp_384_16

17. Alexander, R., El-Moalem, H. E., Gan, T. J. (2002). Comparison of the morphine-sparing effects of diclofenac sodium and ketorolac tromethamine after major orthopedic surgery. Journal of Clinical Anesthesia, 14 (3), 187-192. doi: http://doi.org/10.1016/s0952-8180(01)00382-8

18. Silvanto, M., Lappi, M., Rosenberg, P. H. (2002). Comparison of the opioid-sparing efficacy of diclofenac and ketoprofen for 3 days after knee arthroplasty. Acta Anaesthesiologica Scandinavica, 46 (3), 322-328. doi: http://doi.org/10.1034/j.13996576.2002.t01-1-460316.x

19. Howard, M. L., Isaacs, A. N., Nisly, S. A. (2016). Continuous Infusion Nonsteroidal Anti-Inflammatory Drugs for Perioperative Pain Management. Journal of Pharmacy Practice, 31 (1), 66-81. doi: http://doi.org/10.1177/0897190016665539

20. Nze, P. U. N., Onyekwulu, F. (2006) Intraoperative Diclofenac for Post-Adenoidectomy Analgesia in Small Children. Nigerian Journal of Clinical Practice, 9 (2), 102-104.

21. Pandit, M. K., Godhi, S., Lall, A. B. (2011). Preoperative Intravenous Tramadol Versus Diclofenac for Preventing Postoperative Pain After Third Molar Surgery: A Comparative Study. Journal of Maxillofacial and Oral Surgery, 10 (4), 306-309. doi: http://doi.org/10.1007/s12663-011-0250-9

22. Alijanpour, E., Khirkhah, F., Bijani, A., Rabiee, M., Jabbari, A., Mortazavi, Y. (2011). Comparison of sodium diclofenac, ketamine and propofol with fentanyl and midazolam in balanced anaesthesia. Anesthesia: Essays and Researches, 5 (2), $176-181$. doi: http://doi.org/10.4103/0259-1162.94760

23. Seymour, R. A., Moore, U., Hawkesford, J., Coulthard, P., Jackson-Leech, D., Thomas, D. et. al. (2000). An investigation into the efficacy of intravenous diclofenac in post-operative dental pain. European Journal of Clinical Pharmacology, 56 (6-7), 447452. doi: http://doi.org/10.1007/s002280000177

24. Zohar, E., Shapiro, A., Eidinov, A., Fishman, A., Fredman, B. (2006). Postcesarean analgesia: the efficacy of bupivacaine wound instillation with and without supplemental diclofenac. Journal of Clinical Anesthesia, 18 (6), 415-421. doi: http://doi.org/10.1016/j.jclinane.2006.01.001

25. McNicol, E. D., Ferguson, M. C., Schumann, R. (2018). Single-dose intravenous diclofenac for acute postoperative pain in adults. Cochrane Database of Systematic Reviews. doi: http://doi.org/10.1002/14651858.cd012498.pub2

26. Colucci, R. D., Wright, C., Mermelstein, F. H., Gawarecki, D. G., Carr, D. B. (2009). Dyloject®, a novel injectable diclofenac solubilised with cyclodextrin: Reduced incidence of thrombophlebitis compared to injectable diclofenac solubilised with polyethylene glycol and benzyl alcohol. Acute Pain, 11 (1), 15-21. doi: http://doi.org/10.1016/j.acpain.2008.11.001 
27. Mermelstein, F., Hamilton, D. A., Wright, C., Lacouture, P. G., Ramaiya, A., Carr, D. B. (2013). Single-Dose and Multiple-Dose Pharmacokinetics and Dose Proportionality of Intravenous and Intramuscular HP $\beta$ CD-Diclofenac (Dyloject) Compared with Other Diclofenac Formulations. Pharmacotherapy: The Journal of Human Pharmacology and Drug Therapy, 33 (10), 10121021. doi: http://doi.org/10.1002/phar.1304

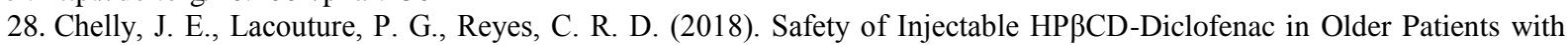
Acute Moderate-to-Severe Postoperative Pain: A Pooled Analysis of Three Phase III Trials. Drugs \& Aging, 35 (3), 249-259. doi: http://doi.org/10.1007/s40266-018-0529-3

29. Leuratti, C., Loprete, L., Rossini, M., Frangione, V., Rovati, S., Radicioni, M. (2019). Pharmacokinetics and Safety of a Diclofenac Sodium $75 \mathrm{mg} / 1 \mathrm{~mL}$ Solution (Akis ${ }^{\circledR} /$ Dicloin $\left.{ }^{\circledR}\right)$ Administered as a Single Intravenous Bolus Injection in Healthy Men and Women. European Journal of Drug Metabolism and Pharmacokinetics, 44 (5), 681-689. doi: http://doi.org/10.1007/s13318-019$00558-8$

30. Gan, T. J., Singla, N., Daniels, S. E., Lacouture, P. G., Min, L. H., Reyes, C. R. D., Carr, D. B. (2016). Cardiovascular safety of hydroxypropyl- $\beta$-cyclodextrin-diclofenac in the management of acute postsurgical pain: a pooled analysis of 2 randomized, double-blind, placebo- and active comparator-controlled phase III clinical trials. Journal of Clinical Anesthesia, 31, 249-258. doi: http://doi.org/10.1016/j.jclinane.2016.01.020

31. Forrest, J. B., Camu, F., Greer, I. A., Kehlet, H., Abdalla, M., Bonnet, F. et. al. (2002). Ketorolac, diclofenac, and ketoprofen are equally safe for pain relief after major surgery. British Journal of Anaesthesia, 88 (2), 227-233. doi: http://doi.org/10.1093/bja/88.2.227

Received date 04.12.2019

Accepted date 12.02.2020

Published date 29.02.2020

Elena Litvinova, Doctor of Pharmaceutical Sciences, Associate Professor, Department of Management and Economics of Enterprise, National University of Pharmacy, Pushkinska str., 53, Kharkiv, Ukraine, 61002

E-mail: hlitvinova@gmail.com 